\title{
The historic reality of the cyclonic variability in French Antilles, 1635-2007
}

\section{E. Garnier ${ }^{1}$, J. Desarthe ${ }^{2}$, and D. Moncoulon ${ }^{2}$}

${ }^{1}$ LIENSs, UMR CNRS-University of La Rochelle 17000 La Rochelle, France

${ }^{2}$ Caisse Centrale de Réassurance, 157 boulevard Haussmann 75 008, France

Received: 4 January 2015 - Accepted: 30 March 2015 - Published: 30 April 2015

Correspondence to: E. Garnier (egarnier.cea-cnrs@orange.fr)

Published by Copernicus Publications on behalf of the European Geosciences Union.
The historic reality of the cyclonic variability in French Antilles

E. Garnier et al.

\section{Title Page}

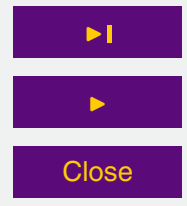

Back

Full Screen / Esc

Printer-friendly Version

Interactive Discussion 


\section{Abstract}

Facing climate change and increasing costs of natural disasters, the exposure evolution analysis requires having a long-term knowledge of the impacts of extreme events. By associating historical and modeling approaches, we aim to build a long term chronol5 ogy of natural disaster severity and damages. To highlight this new methodology, the overseas departments of French Antilles have been chosen. These territories are strongly exposed to natural disasters, particularly hurricanes. The search with historical archives made it possible to reconstruct, for the first time, the chronology and severity of hurricanes since the 17th century. During the 20th century, a significative increase in the number of cyclones has occurred after the 1950s. The analysis of a longer historical period (since the 1630s) allows us to temperate this idea by showing intensive cyclonic period in the past centuries.

\section{Introduction}

Governments and private societies have to deal with increasing cost of natural dis15 asters (Swiss Re, 2013, WMO, 2014). In 2011, natural disaster economic losses are estimated to USD 380 billion in the world (Swiss Re, 2013). In 2012, hurricane Sandy was estimated to USD 50 billion for USA (WMO, 2014). In France, the major insurance losses for natural disasters, estimated by French reinsurance company Caisse Centrale de Réassurance (CCR) are: summer 2003 drought (EUR 1.2 billion), Rhône floods in December 2003 (EUR 750 million) and Xynthia storm surge in February 2010 (EUR 770 million).

Beyond the matter of natural disaster cost increase, the International Panel on Climate Change (IPCC) points out that it is "virtually certain in North Atlantic" that there is an increase in the activity of intense tropical cyclones since 1970 (IPCC, 2013; Kossin et al., 2007). On the other hand, the lack of long time series - i.e. the disparity of informations and methods of observation - prevents long-term analysis, prior to 1970

\section{CPD}

$11,1519-1550,2015$

The historic reality of the cyclonic

variability in French Antilles

E. Garnier et al.

\section{Title Page}

Abstract Introduction

Conclusions References

Tables Figures

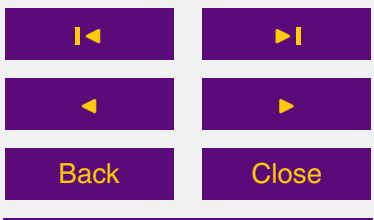
Full Screen / Esc

Printer-friendly Version

Interactive Discussion 
(SREX, 2012; Landsea et al., 2006; Holland and Webster, 2007; Landsea, 2007; Mann et al., 2007a and b). According to IPCC, the frequency of storms is of limited use if not combined with measures of intensity (IPCC, 2013). Several studies have attempted to establish a hurricane intensity chronology. For example, in the Southwest of the United 5 States, the data supplied by six tide gauges were used to rebuild hurricane intensity since 1923 (Grinsted et al., 2012). Nevertheless, it is possible to widen considerably the chronology of cyclone intensity.

To achieve this, an historical approach was conducted. Such an approach requires the capabilities and methods unique to the historical discipline and provide with original 10 and unpublished data extracted from sufficiently homogeneous and plentiful archives to the modellers. It is then possible to widen considerably the chronology of cyclones. On the other hand, the experts are categorical in declaring that there is a low confidence for the evolution of tropical cyclone frequency over the long term.

This paper presents a new historical dataset of tropical cyclones in the French 15 Antilles - since 1635 - collected directly from French archives situated in mainland France or on the islands of Guadeloupe and Martinique. This work differs from previous researches because the majority of the works realized in the past 60 years, even the most recent, are satisfied with reconstructing long term series of cyclones in the Caribbean basin from second hand sources generally written in the 19th century (Poey, 20 1856; Melero, 1870; Romer, 1932). So, the majority of them use compiled historical data, often recopied with errors and without really checking their sources (Millas, 1968; Caviedes, 1991). Chenoweth is one of the very rare researchers to have realized an in-depth work of evaluation of the printed sources (2006) and exploitation of primary sources (2008) derived from archives on the scale of the Lesser Antilles.

Associating historians and modelers, this article demonstrates the originality and the interest of multidisciplinary survey to analyze society exposure to extreme events such as hurricanes. We provide qualitative approach of cyclones. De facto, we take into account the intensity of the phenomena on the particularly exposed territories that are French Antilles. A cyclone observed in the Caribbean basin (Caviedes, 1991;

\section{CPD}

11, 1519-1550, 2015

The historic reality of the cyclonic

variability in French Antilles

E. Garnier et al.

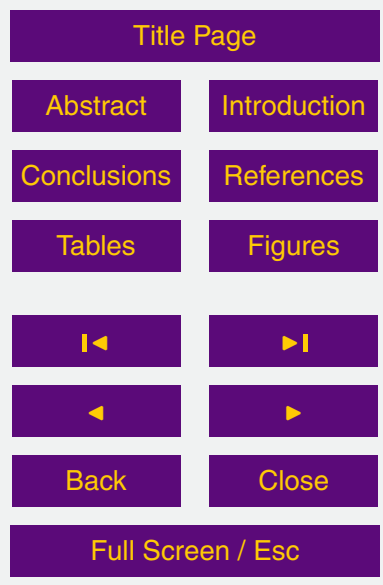

Printer-friendly Version

Interactive Discussion 
Chenoweth, 2006) can have had no significant impact in French Antilles. For that reason we are studying only the events having struck these islands directly because they have been perfectly documented in the archives for more than 300 years.

\section{The stakes of the study}

5 They are based essentially on the vulnerability of French Antilles in face of tropical cyclones and on the weakness of the scientific studies concerning them, both in French and in the English language.

\subsection{A vulnerable territory}

The French Antilles correspond to the French islands of the Caribbean. They belong 10 the North and the coast of Venezuela in the South. We distinguish the Greater Antilles in the North (Cuba, Haiti, Dominican Republic, Jamaica, Puerto Rico) and the Lesser Antilles composed of dozens of small islands to which the French Antilles belong.

Two bigger islands are Guadeloupe and Martinique (Fig. 1). Guadeloupe and its 15 islands (Marie Galante, La Désirade, Les Saintes), the islands of the North (St Barthelemy, St Martin) and Martinique benefit from a tropical climate. This one consists of a dry season called "fasting" and a wet season called "winterising". The cyclone season spreads between July and November, in the course of which period cyclones form in the Atlantic Ocean which can affect the French Antilles. Having exploited tropical crops such as the banana and sugar cane for more than three centuries, the economy of these islands turned towards to the tourism in the 1960s. The latter is the reason for a concentration of the population and activities on the coast.

The French Antilles are particularly vulnerable to cyclones and to tropical depressions because they possess big systems of steep hillsides which dominate a densely

\section{CPD}

$11,1519-1550,2015$

The historic reality of the cyclonic

variability in French Antilles

E. Garnier et al.

\section{Title Page}

Abstract

Conclusions Introduction References

Tables Figures

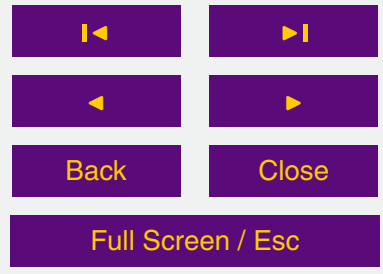

Printer-friendly Version

Interactive Discussion 
trasts which amplify the problems. Since the second half of the 19th century, a large part of the population lives on the coast. Nowadays, the very strong urbanization of the coast and the economic activities create a very important vulnerability in face of cyclones and of their associated impacts such as precipitation, floods, landslides and 5 storm surges. For example, today in Martinique, $62 \%$ of infrastructure and $50 \%$ of the population is concentrated on a surface of only $170 \mathrm{~km}^{2}$ which is very highly exposed to the risks (La documentation Française, 2012).

\subsection{Their place in the scientific plan}

The majority of the studies dedicated today to the Caribbean basin ignore French Antilles for purely political and linguistic reasons. Since the 1960s, the authors have generally been South American or Anglo-Saxons, and as a consequence they mostly used data stemming from former Spanish or British colonies, while the French islands were widely neglected, probably for linguistic reasons and because of the geographical distance of the documentation. So, an in-depth reading of the works of Hispanic authors 15 (Melero, Millas) and Anglo-Saxons (Caviedes, Chenoweth) show that they primarily favored the islands of the Greater Antilles such as Haiti, Cuba, Puerto Rico, Jamaica and paid little attention to the Lesser Antilles. This impression is confirmed by the weakness of the French bibliographical references in their sources. Caviedes (1991) quote none from it while he uses numerous Spanish references.

20 For his part, Chenoweth (2006) quotes only two French references and only eight events out of 118 concern Martinique and/or Guadeloupe. In his work on the Lesser Antilles (2008), of which the French Antilles are a part, no French bibliographical or archival references appear. As a consequence, this major part of the Caribbean basin is widely neglected for climatic research in the scientific plan, in spite of the fact that 25 it can provide solid and long data series which will help towards a better evaluation of the cyclonic exposure variability in the region.

\section{CPD}

$11,1519-1550,2015$

The historic reality of the cyclonic

variability in French Antilles

E. Garnier et al.

\section{Title Page}

Abstract Introduction Conclusions References Tables Figures

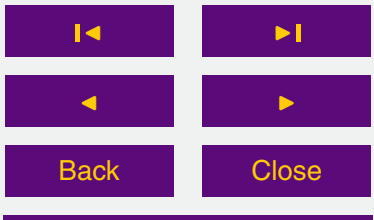
Full Screen / Esc

Printer-friendly Version

Interactive Discussion 


\section{Cyclone data and its interpretation}

We present in this chapter the inventory of the available archives as well as the method used to quantify and estimate the severity of the historic cyclones of French Antilles.

\subsection{An exceptional documentation}

5 As in mainland France or in other French overseas territories, the volume and the quality of the available archives for the French Antilles are explained by their importance in the context of the strategic and economic rivalry between the French and the English. In the ranking of archives, we distinguish the pre-revolutionary period (before 1789) from the contemporary period between 1789 and today.

10 Because of the early creation of a royal administration on these islands and then the actions of the republican administration, we have voluminous archives, which because they were drafted mainly according to standardized administrative procedures are homogeneous and chronologically continuous. Indeed, these archives of overseas department and territories kept today in the French national archives (Aix-en-Provence)

15 and in the departmental archives of Martinique and Guadeloupe contain no chronological gaps since 1635 .

\subsubsection{Travel books (1630s-1660s)}

The oldest documents consist of travel books written by the first French colonists to settle in the region around 1630. Most of the time they use a retrospective approach and indirect testimonies. Nevertheless, their contents seem reliable because the authors of these narratives belong either to the order of the Jesuits or to that of the Dominicans. These religious congregations were recognized for the intellectual qualities of their members. The Jesuit Jean-Baptiste Chanvalon was a correspondent of the royal Academy of the Sciences of Paris. Mainly, these works deliver a comprehensive view

\section{CPD}

$11,1519-1550,2015$

The historic reality of the cyclonic

variability in French Antilles

E. Garnier et al.

\section{Title Page}

Abstract

Conclusions

Tables

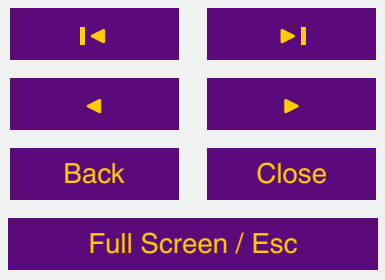

Printer-friendly Version

Interactive Discussion 
countered by the newly-arrived Europeans), cultural and physical (geology, geography, natural history) observations.

\subsubsection{The royal administration}

In 1664, Louis XIV's finance minister, Colbert, created the French West Indies com5 pany which received the property of all the lands conquered in the Caribbean. Ten years later, the bankruptcy of this company imposed a direct takeover by the king. The French Antilles were under the authority of the governor general of the French Antilles and a governor is appointed in each island with military power. From 1670s, the administrative task is for the intendant with the charge of justice, the police and finance. By 10 the part of the Antilles in the kingdom's economy, the local authority informs the king about damages of natural disasters. In 1789, the French Antilles represented $37 \%$ of all the imports into the kingdom of France. These reports, letters and inquiries, constitute the documentary base of the present research. The first administrative mention of an extreme event appears in 1672, on the occasion of a cyclone which affected 5 Martinique on 24 September 1672:

The island was visited by a hurricane. Martinique suffered from terrible losses. Sugar canes were uprooted, hundreds of Slave huts and dozens of colonial houses were torn away and some hang on trees. Mills and sugar refineries were knocked down. They can fortunately be rebuilt but the biggest devastation is the tidal wave which demolished a large number of buildings of the city of Saint Pierre from the fortress up to the river the distance of which is 800 feet (approximately $600 \mathrm{~m}$ ). So, there are no traces anymore of houses here. The fury of the sea even shook the stone fort facing the sea.

Source: ANOM COL 8A, folio 190.

\subsubsection{The post-revolutionary archives (after 1789)}

25 From the 1850s new administrative institutions such as the "commune" and the "Conseil général" (local political assembly) joined the governor in the management of natural

\section{CPD}

$11,1519-1550,2015$

The historic reality of the cyclonic

variability in French Antilles

E. Garnier et al.

\section{Title Page}

Abstract Introduction Conclusions References Tables Figures

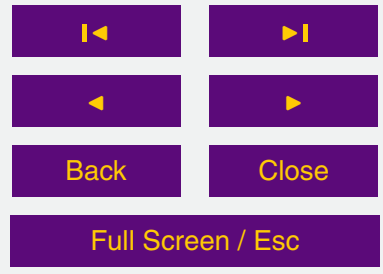

Printer-friendly Version

Interactive Discussion 
disasters. From now on, any disaster brings the mayor of the commune to address the Governor and through him, the Colonial Secretary. He enumerates exactly the number of houses and the damaged agricultural land. So, the quality of the documentation of catastrophes takes advantage of these new relations established between the lo5 cal level (municipality) and the central power. The local persons in charge inform the mainland of the situation on the island and draft statements of the damage.

These reports also allow us to understand the progress of the disaster, from the first phase of alert to the last phase of emergency assistance. From the late 19th, reports are enhanced with instrumental observations reported by sailors and weather-

10 men. Since 1946, the "préfets" (local representative of the State) replace the governors and their reports become even more detailed thanks to minutes of the crisis meetings between the various political and economic actors during and after the cyclone.

\subsection{The method of reconstruction}

The French archives contain very rich information concerning the damage engendered 15 by cyclones. This "damage" data enable an extremely reliable evaluation of the severity of a cyclone according to the SSHWS, even for very old events. This is not the case for documents consulted by other researchers over the past 20 years. They have therefore had much more difficulty distinguishing between the severity of of different cyclones, in particular distinguishing between major hurricanes of categories 4 and 5 and other 20 hurricanes of category 3 (Chenoweth and Divine, 2008).

Historical data collected in archives have been grouped in a database. In a first phase, a chronology of hurricanes since the 1630s has been created then classified according to the severity of every event.

In recent years, numerous studies have used the Fujita scale to try to measure the 25 severity of hurricanes (Boose, 2004; Chenoweth and Divine, 2012; Edwards et al., 2013). In our work, we choose the Simpson-Saffir Hurricane Wind Scale (SSHWS) to measure the strength of cyclones (Saffir, 1973; Simpson, 1974). Indeed, the Fujita scale is designed to measure the intensity of tornados. Its application to tropical

\section{CPD}

$11,1519-1550,2015$

\section{The historic reality of the cyclonic \\ variability in French Antilles \\ E. Garnier et al.}

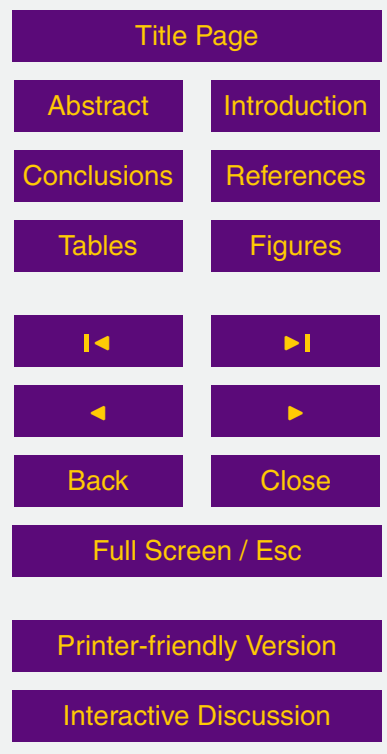


cyclones seems thus inappropriate because the phenomena (tornados and cyclones) have different physical characteristics. In particular, a cyclone lasts several days while the duration of a tornado is only a few hours. On the other hand, the SSHWS is used nowadays by all the meteorological organizations because it begins where the Beau5 fort scale stops (the Force 12 Beaufort corresponds to the category 1 of SSHWS). The addition of a new class in the SSHWS is often proposed further to the recording of even greater speeds during cyclones (ex: $345 \mathrm{~km} \mathrm{~h}^{-1}$ in 1961). But above all, it gives an estimation of the damage caused by hurricanes. Created in 1969 by Herbert Saffir, a consultant engineer and Robert Simpson, a manager of the National Cyclone Center, 10 the SSHWS gives examples of types of damage caused by winds and classify cyclones according to five categories. In this paper we propose to adapt the SSHWS according the historical documentation to create a new classification, the Historical Hurricane Wind Scale or HHWS (Table 1).

Later it was improved by adding other additional parameters such as storm surges 15 and floods. If the scale does not give complete satisfaction as a tool for estimating recent hurricanes, it is on the other hand particularly suited for application to the contents of the archives which are especially descriptive up to the 1880s (see the extract of archives above). After this date, sources also provide numerous additional meteorological data. They sometimes record a cyclone on a precise date without providing 20 enough information to classify it on the HHWS. In this case, we chose to attribute it an index 1 , so that it appears on the chronological graph but without an estimate of its severity.

\section{CPD}

$11,1519-1550,2015$

The historic reality of the cyclonic

variability in French Antilles

E. Garnier et al.

\section{Title Page}

Abstract Introduction Conclusions References Tables Figures

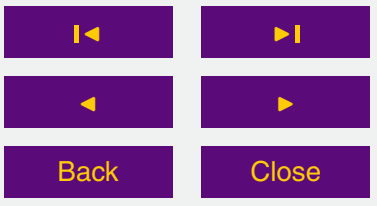

Full Screen / Esc

Printer-friendly Version

Interactive Discussion 


\section{Results and discussion}

\subsection{Variability and fluctuations in cyclones in French Antilles since 1635}

Between 1635 and 2007, French Antilles underwent 91 events. The ranking of these cyclones according to the Historical Hurricane Wind Scale divides up between 33 events

5 of type -1 and 58 hurricanes (Table 2).

Historical reconstruction reveals strong fluctuations since the 17th century (Fig. 2). It does not demonstrate a real trend. In the 17th century, which begins in 1635 in the series, there were 18 events including 10 hurricanes. The return period of hurricanes is around 10 years. On the other hand, 18th and 19th centuries appear to have been intensive cyclonic periods, the return period is estimated for both to 6 years. For major hurricanes (events between category 3 and 5 ), the return period is estimated to 12 years for the 18th century, and to 10 years for the 19th. Only 13 hurricanes are identified for the 20th but 8 are major hurricanes. The estimated return periods are 8 years for hurricane and 12 years for events between category 3 and 5 .

The distribution by half centuries refines these results (Fig. 3) by showing that the period 1750-1850 corresponds to the longest and most intense cyclonic episode in French Antilles. There were a total of 35 events out of a total of $91(38.4 \%)$ over the whole four centuries in the study. Since the early 20th century, 19 events $(20.4 \%)$ including 13 hurricanes were identified with a very clear increase in the number of 20 hurricanes in the second half of the century.

From 1956, the frequency between events averages around 4 years. Nevertheless, we observe a slowing down of this frequency since 1979, in spite of the particularly destructive cyclone (category 4) of 1989. Contrary to previous studies, our results do not reveal a stronger cyclonic activity since 1995 (Goldenberg et al., 2001; Landsea

\section{CPD}

11, 1519-1550, 2015

The historic reality of the cyclonic

variability in French Antilles

E. Garnier et al.

\section{Title Page}

Abstract Introduction Conclusions References Tables Figures

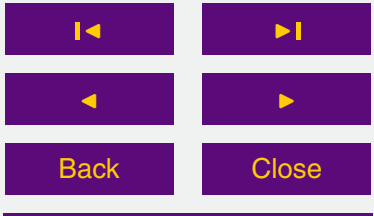
Full Screen / Esc

Printer-friendly Version

Interactive Discussion 
During the four centuries in the study of French Antilles, there is no clear trend to prove a real contemporary change in the severity of cyclones. In fact categories 4 and 5 events had an important decrease or a total disappearance between 1850 and 2000 . As a consequence, the most extreme cyclones (index 5) are not more numerous than 5 before in this part of the Caribbean. On the other hand, the events between categories 2 and 3 progress appreciably for the same period. From the perspective of a better adaptation of the island societies and a reduction in their vulnerability, the events with the highest average frequency are classes 1 and 2 with respectively 6 and 8 years while category 3 is around 12 years (Table 4 ).

10 Nevertheless, it is necessary to underline that the cyclones of low intensity (categories 1 to 3) can be accompanied by floods and storm surges which increase the vulnerability of societies considerably. During 372 years studied, $20 \%$ of cyclones were associated with floods and $37 \%$ with storm surges, significant enough to be reported in the historical archives. But both phenomena struck Martinique and Guadeloupe during 15 a cyclone at the same time only twice.

\subsection{Regional comparison}

Divine and Chenoweth (2008) list 292 tropical storms in the Lesser Antilles between 1690 and 2006 while only 91 events were listed in the archives of French Antilles. Like ourselves, they consider that there is no significant trend in tropical cyclones between 201700 and 2007 and they also observe a decrease of $20 \%$ of these disasters in the 20th century. These results also coincide with the south of Florida (Elsner et al., 2004). On the other hand, they note that cyclones are less and less numerous in the Lesser Antilles while in fact their number increases significantly in the French Antilles after 1956 up to the 1990s. For them, the period 1968-1977 is probably the least active 25 since the beginning of colonization (around 1630).

We consider however that our results about the frequency and the severity of cyclones are robust because of the quality of our archives, which have to date been little taken into account by the other researchers who have worked on the Caribbean. As

\section{CPD}

11, 1519-1550, 2015

\section{The historic reality of the cyclonic \\ variability in French Antilles \\ E. Garnier et al.}

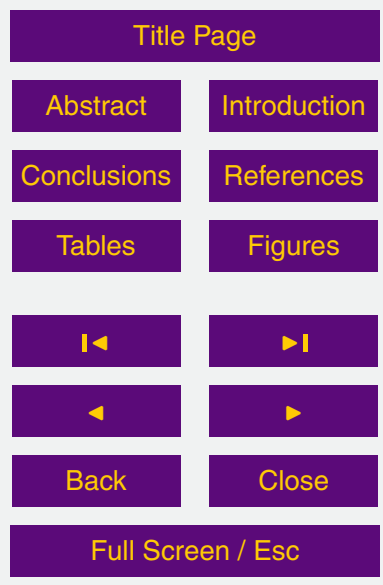

Printer-friendly Version

Interactive Discussion 
shown in Table 4, the historical series of Caviedes (1991) and Chenoweth (2006) coincide little with that of the French Antilles. In his very exhaustive chronology of the Lesser Antilles, Chenoweth (2006) quotes only 10 events for Martinique and for Guadeloupe out of a total of 118 cyclones between 1700 and 1855. In terms of chronological con5 cordance, only $20.3 \%$ of cyclones listed by Caviedes correspond to a French event. On the other hand, in the historic series of Chenoweth 2006, 69.2\% cyclones having affected Lesser Antilles also appear in our French series.

The French archives contain very rich information concerning the damage engendered by cyclones. This "damage" data enable an extremely reliable evaluation of the 10 severity of a cyclone according to the HHWS, even for very old events. This is not the case for documents consulted by other researchers over the past 20 years. They have therefore had much more difficulty distinguishing between the severity of different cyclones, in particular distinguishing between major hurricanes of categories 4 and 5 and other hurricanes of category 3 (Chenoweth and Divine, 2008).

\section{Conclusions}

The available archives in the French mainland, in Guadeloupe and in Martinique provide documentation which is exceptional, as much for its volume and its contents as for its chronological continuity since 1635 . Thanks to them and because this part of the Caribbean has been little addressed in the bibliography of the last thirty years, 20 we have been able to establish a new chronological series of cyclones. Indeed, previous studies have used essentially second hand sources containing frequent errors or approximations. For the four centuries of the study, our series reveals a very strong variability of the cyclonic activity with an increase of events between 1750 and 1850 then a decreasing trend up to the 20th century. For this century nevertheless, a turning point is observable from 1956 with a definite increase in cyclones which slows down strongly again after 1979 . Since this date, nothing supports any climate change from the observation of cyclones. The second contribution of this research is based on the

\section{CPD}

$11,1519-1550,2015$

\section{The historic reality of the cyclonic \\ variability in French Antilles \\ E. Garnier et al.}

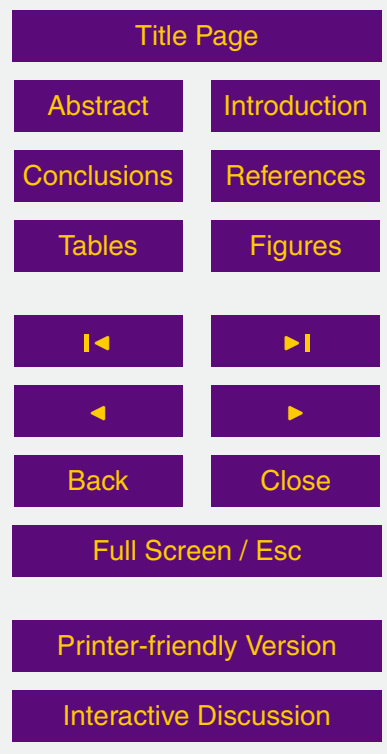


evaluation of the severity of the cyclones of the last four centuries through use of the damage described in archives and of contemporary meteorological data when they are available. This indicator is indeed rarely taken into account by the specialists. We thus use these contents to adapt it to the SSHWS and so estimate the severity of the 5 historical cyclones according to six index of damage. Once more, no trend appears between 1639 and 2007 which would allow us to speak of a worsening severity. For the period 1900-2007, among 19 listed cyclones, none reaches index 5 and only three correspond to a level 4 on the SSHWS.

In the context of these findings, it seems consequently more relevant to consider the 10 data from the perspective of adaptation in the face of cyclonic risk, particularly in terms of reduction of the social and economic vulnerabilities to the associated effects of the cyclones such as floods and storm surges. Indeed, even if a worsening of the cyclone phenomenon cannot be demonstrated, on the other hand the increasing vulnerability of the islanders is indisputable. Historical data have strategic relevance because they describe the demographic and material consequences of these extreme events and underline the historical extent of territories at risk of cyclone damage before the massive urbanization of the Antilles. Better still, they reveal the weaknesses but also the strategies of impact resilience developed by the former societies in the areas of architecture, land settlement and alarm systems. Finally, these social data can constitute an excellent tool of mediation to facilitate the dialogue between policy-makers and local populations and the implementation of consensual measures of adaptation.

The increase of calibration data resulting from historical archives researches is used to strengthen the models. The historical chronology is used to estimate occurrence probability based on long-term period analysis. These data represent the only possible validation of fictive event set developed and proposed in the Cat Models (Risklink RMS, JCALF JBA, ...). The next step of this study is to create hazard models based on the informations from the archives. The major hazards (seasurge, pluvial floods and wind) that occur during a hurricane will be simulated to map the impacted areas. Then, the damage models, based on damage curbs and recent insurance portfolios (with

\section{CPD}

11, 1519-1550, 2015

The historic reality of the cyclonic

variability in French Antilles

E. Garnier et al.

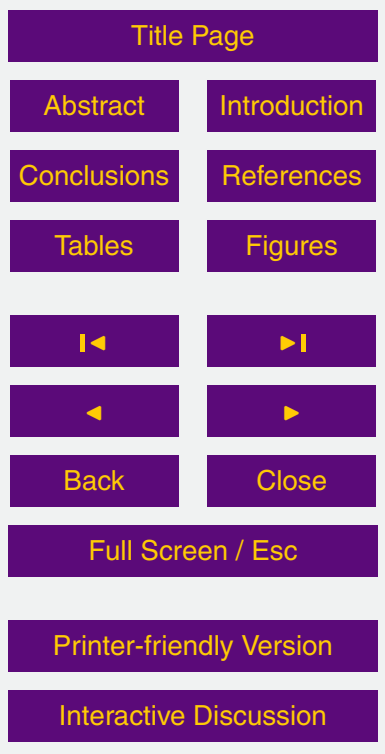


detailed informations on the risks and adress-precision geocoding) will be applied on the historical event to estimate their as-if losses if they would occur today.

Acknowledgements. The article result of a project funded and led by the Caisse Centrale de Réassurance, French reinsurance company.

\section{References}

Boose, E. R.: A method for reconstructing historical hurricanes, in: Hurricanes and Typhoons, Past, Present and Future, edited by: Murnane, R. J. and Liu, K. B., Columbia University Press, New York, 99-120, 2004.

Caviedes, C. N.: Five hundred years of hurricanes in the Carribean: their relationship with global 10

Caviedes, C. N.: El Nino in History, Storming Through the Ages, University Press of Florida, Gainsville, 2001.

Chanvalon, J. B. T.: Voyage à la Martinique contenant diverses observations sur la physique, l'histoire naturelle, l'agriculture, les Mœurs et les usages de cette Isle faites en 1751 et dans les années suivantes, Bauche, Paris, 1761.

Chenoweth, M.: A reassessment of historical Atlantic basin tropical cyclone activity, 1700-1855, Climatic Change, 76, 169-240, 2006.

Chenoweth, M. and Divine, D.: A document-based 318-year record of tropical cyclones in the Lesser Antilles, 1690-2007, Geochem. Geophy. Geosy., 9, 1-21, 2008.

Chenoweth, M. and Divine, D.: Tropical cyclones in the Lesser Antilles: descriptive statistics and historical variability in cyclone energy, 1638-2009, Climatic Change, 113, 583-598, 2012.

Dutertre, J. B.: Histoire générale des Antilles Habitées par les François, Thomas Jolly, Paris, 1667.

Edwards, R., LaDue, J. G., Ferree, J. T., Scharfenberg, K., Maier, C., and Coulbourne, W. L.: 2013.

Elsner, J. B., Xufeng, N., and Jagger, T. H.: Detecting shifts in hurricanes rates using a Markov Chain Monte Carlo approach, J. Climate, 17, 2652-2666, 2004.

CPD

$11,1519-1550,2015$

The historic reality of the cyclonic

variability in French Antilles

E. Garnier et al.

\section{Title Page}

Abstract Introduction

Conclusions References

Tables Figures

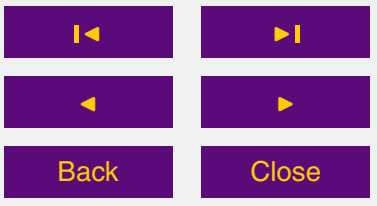

Full Screen / Esc

Printer-friendly Version

Interactive Discussion 
Garcia-Herrera, R., Gimeno, L., Ribera, P., Hernandez, E., Gonzalez, E., and Fernandez, G.: Identification of Carribean basin hurricanes from Spanish documentary sources, Climatic Change, 83, 55-85, 2007.

Grinsted, A., Moore, J. C., and Jevrejeva, S: Homogenous record of Atlantic hurricane surge threat since 1923, P. Natl. Acad. Sci. USA, 109, 19601-19605, 2012.

Holland, G. J. and Webster, P. J.: Heightened tropical cyclone activity in the North Atlantic Natural variability or climate trend?, Philos. Trans. A Math. Phys. Eng. Sci., 365, 2695-2716, 2007.

IPCC: Managing the Risks of Extreme Events and Disasters to Advance Climate Change Adaptation, special report of Intergovernmental Panel on Climate Change, Cambridge University Press, Cambridge, UK, and New York, 161-163, 2012.

IPCC: Climate Change 2013, The Physical Science Basis, Contribution of Working Group to the Fifth Assessment Report of the Intergovernmental Panel on Climate Change, Cambridge University Press, Cambridge, UK, New York, USA, 216-217, 2013.

Knapp, K. R., Kruk, M. C., Levinson, D. H., Diamond, H. J., and Neumann, C. J.: The International Best Track Archive for Climate Stewardship (IBTrACS), B. Am. Meteorol. Soc., 91, 363-376, 2010.

Kossin, J. P., Knapp, K. R., Vimont, D. J., Murnane, R. J., and Harper, B. A.: A globally consistent reanalysis of hurricanes variability and trends, Geophys. Res. Lett., 34, 1-6, 2007.

20 Knutson, T. and Mc Bride, J.: Tropical cyclone and climate change, Nat. Geosci., 3, 157-163, 2010.

Labat, J. B.: Nouveau Voyage aux Isles de l'Amérique, Contenant l'histoire Naturelle de ces Pays, l'Origine, les Mœurs, la Religion et le Gouvernement des Habitants Anciens et Modernes, les Guerres et les Événements Singuliers qui y sont Arrivez... le Commerce et les Manufactures qui y Sont Établies, Cavelier, Paris, 1722.

Landsea, C. W.: Counting Atlantic tropical cyclones back to 1900, EOS Transactions, American Geophysical Union, 88, 197-208, 2007.

Landsea, C. W., Bell, J. D., Gray, W. M., and Goldenberg, S. B.: The extremely active 1995 Atlantic hurricane season: environmental conditions and verification of seasonal forescasts, Mon. Weather Rev., 126, 1174-1193, 1998.

Landsea, C. W., Harper, B. A., Hoareau, K., and Knaff, J. A.: Can we detect trends in extreme tropical cyclones?, Sciences, 313, 452-454, 2006.
CPD

11, 1519-1550, 2015

The historic reality of the cyclonic

variability in French Antilles

E. Garnier et al.

\section{Title Page}

Abstract Introduction

Conclusions References

Tables

Figures

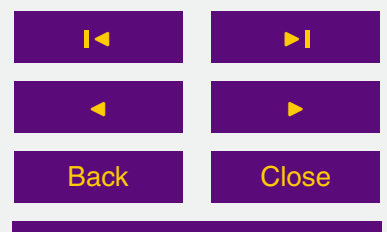

Full Screen / Esc

Printer-friendly Version

Interactive Discussion 
Mann, M. E., Sabbatelli, T. A., and Neu, U.: Evidence for a modest undercount bias in early historical Atlantic tropical cyclone counts, Geophys. Res. Lett., 34, L22707, 1-6, 2007a.

Mann, M. E., Emanual, K. A., Holland, G. J., and Webster, P. J.: Atlantic tropical cyclones revisited, EOS Transactions, American Geophysical Union, 88, 349-350, 2007b.

5 Mann, M. E., Woodruff, J. D., Donnelly, J. P., and Zhang, Z.: Atlantic hurricanes and climate over the past 1500 years, Nature, 460, 880-883, 2009.

Moncoulon, D., Labat, D., Ardon, J., Leblois, E., Onfroy, T., Poulard, C., Aji, S., Rémy, A., and Quantin, A.: Analysis of the French insurance market exposure to floods: a stochastic model combining river overflow and surface runoff, Nat. Hazards Earth Syst. Sci., 14, 2469-2485, doi:10.5194/nhess-14-2469-2014, 2014.

Melero, M. T.: Los huracanes de la Isla de Cuba, Habana, Anales de la Academia de Ciencias Medicas, Fisiscas y Naturales, 124 La Habana, 1870.

Millas, J. C.: Hurricanes of the Carribean and Adjacent Regions, 1492-1800, Academy of the Arts and Sciences of the Americas, 328, Miami, 1968.

15 ONERC: Les Outre-mer Face au défi du Changement Climatique, Rapport au Premier Ministre et au Parlement, La Documentation Française, Paris, 2012.

Pelleprat, P.: Relation des Missions des PP de la Compagnie de Jésus dans les Isles et dans la Terre Ferme de l'Amérique Méridionale, Cramoisy, 121, Paris, 1655.

Poey, A.: Chronological table of cyclonic hurricanes, Journal of the Royal Geographical Society, $20 \quad 25,291-328,1856$.

Quinn, W., Neal, V. T., and Mayolo, S. A.: El Nino occurrences over the past four and a half centuries, Journal of Geographical Research, 92, 14449-14463, 1987.

Rochefort, C.: Histoire Naturelle et Morale des îles Antilles de l'Amérique, Leers, Rotterdam, 1658.

25 Romer, A.: Les Cyclones à la Martinique, Imprimerie du Gouvernement, Fort de France, 1932.

Rufz de Lavison, E.: Etudes Historiques et Statistiques sur la Population de la Martinique, Impr. de Carles, St-Pierre, 1850.

Saffir, H. S.: Hurricane wind and storm surge, The Military Engineer, 423, 4-5, 1973.

Simpson, R. H.: The Hurricane disaster potential scale, Weatherwise, 27, 169-186, 1974.

30 WMO: Atlas of Mortality and Economic Losses From Weather, Climate and Water Extremes (1970-2012), World Meteorological Organization, 1123, Geneva, 2014.

\section{Archives}

\section{CPD}

11, 1519-1550, 2015

The historic reality of the cyclonic

variability in French Antilles

E. Garnier et al.

\section{Title Page}

Abstract

Introduction

Conclusions References

Tables

Figures

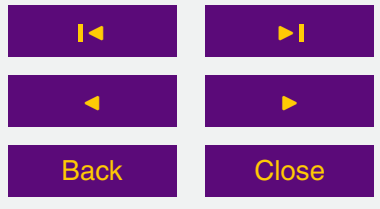

Full Screen / Esc

Printer-friendly Version

Interactive Discussion 
Departmental archives of Guadeloupe

$5 \quad$ Série continue: descriptions, damages and risk management on hurricane (1928-1989)

$7 \mathrm{~W}$ : local administration during hurricanes (1956)

\section{Departmental archives of Martinique}

$1 \mathrm{M}$ : governor administration during natural disasters (1789-1945)

$101158 \mathrm{~W}$ : local administration during hurricanes (since 1945)

6 S: Risk management (20th century)

National archives of the overseas (Aix-en-Provence)

Série géographique: 2400COL92: damages and helps of natural disaster (1913-1893)

15 Fonds Ministériel: Guadeloupe: carton 42, 60, 118, 129, 147, 244 ; Martinique: carton 70, 76, 103

Travaux publics: Guadeloupe, cartons 440, 1157

Affaires politiques: carton 782

Secrétariat d'Etat à la Marine: C7A - Correspondence from Guadeloupe (1649-1815);

$$
\text { C8A - Correspondence from Martinique (1635-1815) }
$$

\section{Printed sources}

\section{Deliberations of the Councils}

25 Conseil Colonial de la Guadeloupe: 1836-1839

Conseil Colonial de la Martinique: $1834-1840$

Conseil Général de la Guadeloupe: 1868-1881

Conseil Général de la Martinique: 1871-1938

\section{CPD}

11, 1519-1550, 2015

The historic reality of the cyclonic

variability in French Antilles

E. Garnier et al.

\section{Title Page}

Abstract

Introduction

Conclusions

References

Tables

Figures

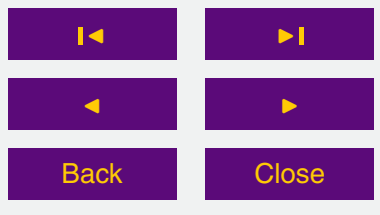

Full Screen / Esc

Printer-friendly Version

Gazette officielle de la Guadeloupe: 1870

Journal officiel de la Guadeloupe: 1882-1936

Journal officiel de la Martinique: 1845-1934

Moniteur de la Martinique. Journal officiel de la colonie: 1891 
Table 1. Reconstruction of the Historical Hurricane Wind Scale (HHWS) according to the historical documentation.

\begin{tabular}{|c|c|c|c|c|c|c|}
\hline & Type of damages accor & ling for historical archive & & Category & Summar & Speed of winds criteria \\
\hline Light contructions & Houses & Tree & Crop & & & \\
\hline & Small events (storms a & nd tropical depressions) & & -1 & & $<118 \mathrm{kmh}^{-1}$ \\
\hline $\begin{array}{l}\text { Wooden structures or } \\
\text { shingles not attached } \\
\text { to the ground by } \\
\text { means of foundations } \\
\text { can be carried off }\end{array}$ & $\begin{array}{l}\text { Houses with frames } \\
\text { can undergo damage } \\
\text { to roofs, gables, or } \\
\text { chimneys }\end{array}$ & $\begin{array}{l}\text { Larges branches of } \\
\text { trees can be snapped } \\
\text { and shallow rooted } \\
\text { trees can be toppled }\end{array}$ & $\begin{array}{l}\text { Sugar cane and other } \\
\text { crops slightly damaged }\end{array}$ & 1 & $\begin{array}{l}\text { Violent winds with some } \\
\text { damage. Example: Hur- } \\
\text { ricane Dean in Mar- } \\
\text { tinique in } 2007\end{array}$ & $119-153 \mathrm{~km} \mathrm{~h}^{-1}$ \\
\hline $\begin{array}{l}\text { Strong probability of } \\
\text { being destroyed }\end{array}$ & $\begin{array}{l}\text { Strong probability of } \\
\text { destruction of roofs. } \\
\text { Non-reinforced walls } \\
\text { could collapse }\end{array}$ & $\begin{array}{l}\text { Many shallow rooted } \\
\text { tress could be } \\
\text { snapped or uprooted } \\
\text { and blocked numerous } \\
\text { roads }\end{array}$ & $\begin{array}{l}\text { Minor destruction of } \\
\text { major crops (cane, } \\
\text { coffee, bananas) mort- } \\
\text { gaging the harvest }\end{array}$ & 2 & $\begin{array}{l}\text { Extremely dangerous } \\
\text { winds with important } \\
\text { damage. Example: } \\
\text { Hurricane Edith in } \\
\text { Martinique in } 1963\end{array}$ & $154-177 \mathrm{~km} \mathrm{~h}^{-1}$ \\
\hline $\begin{array}{l}\text { High level of destruc- } \\
\text { tion, collapse of walls }\end{array}$ & $\begin{array}{l}\text { According to the } \\
\text { state of construction, } \\
\text { houses could be de- } \\
\text { stroyed by the removal } \\
\text { of the roof or only } \\
\text { damaged (windows, } \\
\text { doors). Non-reinforced } \\
\text { walls collapse }\end{array}$ & $\begin{array}{l}\text { Many trees wil be } \\
\text { snapped or uprooted } \\
\text { blocking numerous } \\
\text { roads }\end{array}$ & $\begin{array}{l}\text { Destructiion of crops } \\
\text { and susbistence farm- } \\
\text { ing. Temporary prob- } \\
\text { lems of food supply }\end{array}$ & 3 & $\begin{array}{l}\text { Devastating damage. } \\
\text { Example: Hurricane } \\
\text { Inez in Guadeloupe in } \\
1966\end{array}$ & $178-208 \mathrm{~km} \mathrm{~h}^{-1}$ \\
\hline $\begin{array}{l}\text { High percentage of de- } \\
\text { struction }\end{array}$ & $\begin{array}{l}\text { High level of destruc- } \\
\text { tion, torn away roofs } \\
\text { and important damage } \\
\text { caused by blown away } \\
\text { materials }\end{array}$ & $\begin{array}{l}\text { Most trees will be } \\
\text { snapped or uprooted } \\
\text { and power poles }\end{array}$ & $\begin{array}{l}\text { Severe destruction of } \\
\text { crops and subsistence } \\
\text { farming. } \\
\text { Significant impact on } \\
\text { the harvest and the ex- } \\
\text { port. Problems of sus- } \\
\text { tainable food supply }\end{array}$ & 4 & $\begin{array}{l}\text { Catastrophic damage. } \\
\text { Example: Hurricane } \\
\text { David in Martinique in } \\
1979\end{array}$ & $209-251 \mathrm{~km} \mathrm{~h}^{-1}$ \\
\hline Complete destruction & $\begin{array}{l}\text { High percentage of de- } \\
\text { stroyed houses. Im- } \\
\text { portant quantity of de- } \\
\text { bris blown by the wind. } \\
\text { Collapse of buildings } \\
\text { in masonry }\end{array}$ & $\begin{array}{l}\text { Nearly all trees are } \\
\text { snapped or uprooted } \\
\text { and power poles caus- } \\
\text { ing power cuts in resi- } \\
\text { dential areas }\end{array}$ & $\begin{array}{l}\text { Complete destruction of } \\
\text { crops and subsistence } \\
\text { farming. Problems of } \\
\text { sustainable food sup- } \\
\text { ply. Important economic } \\
\text { losses }\end{array}$ & 5 & $\begin{array}{l}\text { Disastrous damage. } \\
\text { Example: Hurricane in } \\
\text { Guadeloupe in } 1865 \text { or } \\
\text { Hurricane in Martinique } \\
\text { in } 1891\end{array}$ & $>252 \mathrm{~km} \mathrm{~h}^{-1}$ \\
\hline
\end{tabular}

\section{The historic reality of the cyclonic variability in French Antilles \\ E. Garnier et al.}

\section{Title Page}

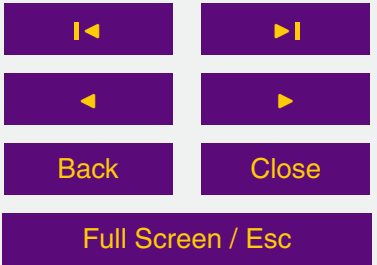

Printer-friendly Version

Interactive Discussion 
Table 2. Distribution by century and by category of hurricanes in the French Antilles.

\begin{tabular}{lllllll}
\hline Period & Cat. 1 & Cat. 2 & Cat. 3 & Cat. 4 & Cat. 5 & Total \\
\hline $1635-1699$ & 2 & 3 & 3 & 2 & 0 & $\mathbf{1 0}$ \\
$1700-1799$ & 5 & 4 & 2 & 3 & 3 & $\mathbf{1 7}$ \\
$1800-1899$ & 3 & 4 & 4 & 3 & 3 & $\mathbf{1 7}$ \\
$1900-1999$ & 3 & 2 & 5 & 3 & 0 & $\mathbf{1 3}$ \\
$2000-2007$ & 1 & & & & & $\mathbf{1}$ \\
\hline Total & 14 & 13 & 14 & 11 & 6 & $\mathbf{5 8}$ \\
\hline
\end{tabular}

CPD

$11,1519-1550,2015$

The historic reality of the cyclonic variability in French Antilles

E. Garnier et al.

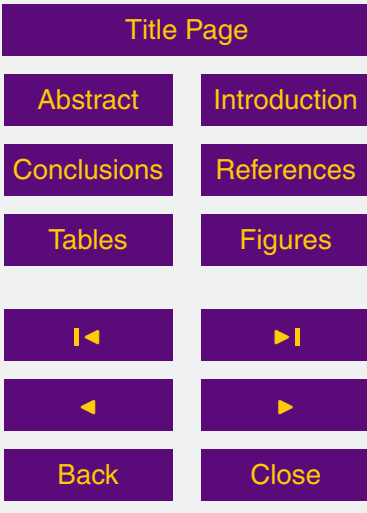

Full Screen / Esc

Printer-friendly Version

Interactive Discussion 
Table 3. Periods of return of cyclones by HSSHWS categories 1635-2007.

\begin{tabular}{lll}
\hline SSHWS categories & Return period & Yearly probability \\
\hline 5 & 62 & 0.02 \\
4 & 21 & 0.05 \\
3 & 12 & 0.08 \\
2 & 8 & 0.12 \\
1 & 6 & 0.16 \\
\hline
\end{tabular}

CPD

11, 1519-1550, 2015

The historic reality of the cyclonic variability in French Antilles

E. Garnier et al.

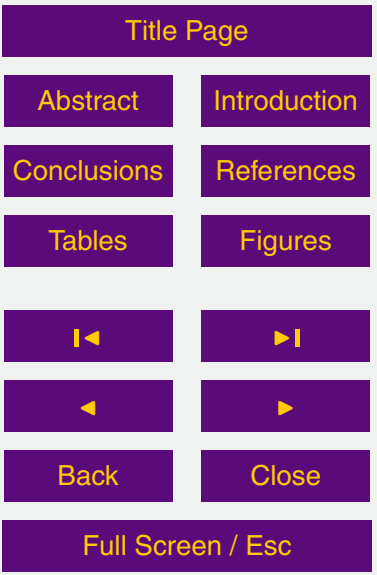

Printer-friendly Version

Interactive Discussion 
Table A1. Comparison between cyclones in the French Antilles (Martinique, Guadeloupe, Saint-Barthelemy, Saint-Martin) and the series of Caviedes (1991) and Chenoweth (2006). The bold dates indicate the common events between Caviedes and the French Antilles series. The italic dates indicate the common events between Chenoweth and the French Antilles series. The bold and italic dates indicate a French cyclone quotation by Chenoweth.

\begin{tabular}{|c|c|c|}
\hline $\begin{array}{l}\text { Caviedes hurricanes } \\
\text { series }\end{array}$ & $\begin{array}{l}\text { Chenoweth cyclones } \\
\text { hurricanes }\end{array}$ & $\begin{array}{l}\text { French Antilles } \\
\text { hurricanes series }\end{array}$ \\
\hline $1656-1988$ & $1700-1855$ & \\
\hline 1656 & & 1656 \\
\hline \multicolumn{3}{|l|}{1660} \\
\hline & & 1666 \\
\hline & & 1667 \\
\hline \multicolumn{3}{|l|}{1671} \\
\hline & & 1672 \\
\hline & & 1680 \\
\hline \multicolumn{3}{|l|}{1681} \\
\hline \multicolumn{3}{|l|}{1688} \\
\hline & & 1692 \\
\hline & & 1693 \\
\hline & & 1694 \\
\hline & & 1695 \\
\hline \multicolumn{3}{|l|}{1696} \\
\hline & & 1699 \\
\hline & 1700 & \\
\hline \multicolumn{3}{|l|}{1701} \\
\hline & 1702 & \\
\hline & 1705 & \\
\hline & 1706 & \\
\hline \multirow[t]{2}{*}{ 1707-1708 } & 1707 & \\
\hline & 1712 & \\
\hline
\end{tabular}

CPD

$11,1519-1550,2015$

The historic reality of the cyclonic

variability in French

Antilles

E. Garnier et al.

Title Page

Abstract

Introduction

Conclusions

References

Tables

Figures

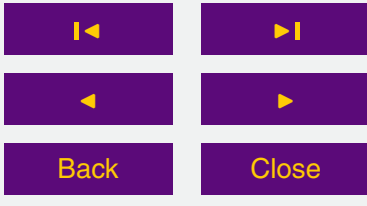

Full Screen / Esc

Printer-friendly Version

Interactive Discussion 
Table A1. Contiued.

\begin{tabular}{|c|c|c|}
\hline $\begin{array}{l}\text { Caviedes hurricanes } \\
\text { series }\end{array}$ & $\begin{array}{l}\text { Chenoweth cyclones } \\
\text { hurricanes }\end{array}$ & $\begin{array}{l}\text { French Antilles } \\
\text { hurricanes series }\end{array}$ \\
\hline & 1713 & 1713 \\
\hline \multirow[t]{10}{*}{1714} & 1714 & \\
\hline & 1715 & 1715 \\
\hline & 1716 & \\
\hline & 1718 & \\
\hline & 1720 & \\
\hline & 1722 & \\
\hline & 1723 & 1723 \\
\hline & 1724 & 1724 \\
\hline & 1725 & \\
\hline & 1726 & \\
\hline \multirow[t]{4}{*}{1728} & 1728 & \\
\hline & 1729 & \\
\hline & 1730 & \\
\hline & 1731 & \\
\hline \multirow[t]{8}{*}{1733} & 1733 & \\
\hline & 1734 & 1734 \\
\hline & 1736 & \\
\hline & 1738 & \\
\hline & 1740 & 1740 \\
\hline & 1743 & \\
\hline & 1744 & \\
\hline & 1746 & \\
\hline \multirow[t]{5}{*}{1747} & 1747 & \\
\hline & 1749 & \\
\hline & 1751 & 1751 \\
\hline & 1752 & \\
\hline & & 1753 \\
\hline
\end{tabular}

CPD

11, 1519-1550, 2015

The historic reality of the cyclonic variability in French Antilles

E. Garnier et al.

\section{Title Page}

Abstract

Introduction

Conclusions

References

Tables

Figures

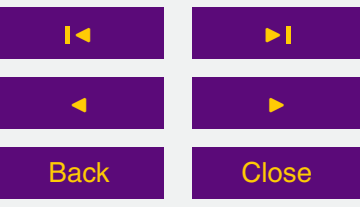

Full Screen / Esc

Printer-friendly Version

Interactive Discussion 
Table A1. Contiued.

\begin{tabular}{|c|c|c|}
\hline $\begin{array}{l}\text { Caviedes hurricanes } \\
\text { series }\end{array}$ & $\begin{array}{l}\text { Chenoweth cyclones } \\
\text { hurricanes }\end{array}$ & $\begin{array}{l}\text { French Antilles } \\
\text { hurricanes series }\end{array}$ \\
\hline & 1754 & 1754 \\
\hline & 1755 & \\
\hline \multirow[t]{4}{*}{1756} & 1756 & 1756 \\
\hline & 1758 & 1758 \\
\hline & 1759 & \\
\hline & 1760 & \\
\hline \multirow[t]{5}{*}{1761} & 1761 & \\
\hline & 1762 & \\
\hline & 1763 & \\
\hline & 1764 & \\
\hline & 1765 & \\
\hline \multirow[t]{4}{*}{1766} & 1766 & 1766-1766 \\
\hline & 1767 & \\
\hline & 1768 & \\
\hline & 1769 & \\
\hline 1771 & 1771 & \\
\hline \multirow[t]{5}{*}{1772} & 1772 & \\
\hline & 1773 & \\
\hline & 1774 & \\
\hline & 1775 & \\
\hline & 1776 & 1776 \\
\hline \multirow{6}{*}{1777} & 1777 & \\
\hline & 1778 & \\
\hline & 1779 & 1779 \\
\hline & 1780 & 1780 \\
\hline & 1781 & \\
\hline & 1782 & \\
\hline 1783 & 1783 & \\
\hline
\end{tabular}

CPD

11, 1519-1550, 2015

The historic reality of the cyclonic variability in French Antilles

E. Garnier et al.

\section{Title Page}

Abstract

Introduction

Conclusions

References

Tables

Figures

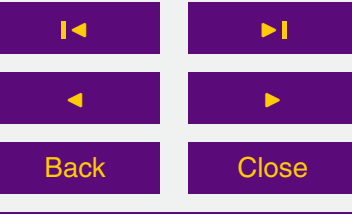

Full Screen / Esc

Printer-friendly Version

Interactive Discussion 
Table A1. Contiued.

\begin{tabular}{|c|c|c|}
\hline $\begin{array}{l}\text { Caviedes hurricanes } \\
\text { series }\end{array}$ & $\begin{array}{l}\text { Chenoweth cyclones } \\
\text { hurricanes }\end{array}$ & $\begin{array}{l}\text { French Antilles } \\
\text { hurricanes series }\end{array}$ \\
\hline & 1784 & \\
\hline & 1785 & \\
\hline & 1786 & \\
\hline \multirow[t]{3}{*}{1787} & 1787 & \\
\hline & 1788 & 1788 \\
\hline & 1790 & \\
\hline \multirow[t]{6}{*}{1791} & 1791 & \\
\hline & 1792 & \\
\hline & 1793 & \\
\hline & 1794 & \\
\hline & 1795 & \\
\hline & 1796 & \\
\hline 1797 & 1797 & \\
\hline \multicolumn{3}{|l|}{1797} \\
\hline \multicolumn{3}{|l|}{1798} \\
\hline \multirow[t]{2}{*}{1824} & 1799 & \\
\hline & 1800 & \\
\hline \multirow[t]{4}{*}{ 1801-1802 } & 1802 & \\
\hline & 1804 & \\
\hline & 1806 & 1806 \\
\hline & 1807 & \\
\hline \multirow[t]{4}{*}{1808} & 1808 & \\
\hline & 1810 & \\
\hline & 1811 & \\
\hline & 1812 & \\
\hline 1813 & 1813 & \\
\hline \multirow[t]{2}{*}{1814} & 1814 & \\
\hline & 1815 & \\
\hline
\end{tabular}

CPD

11, 1519-1550, 2015

The historic reality of the cyclonic

variability in French Antilles

E. Garnier et al.

\section{Title Page}

Abstract

Introduction

Conclusions

References

Tables

Figures

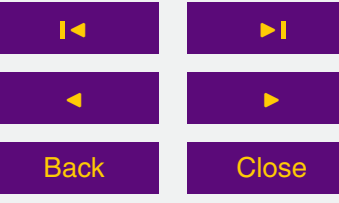

Full Screen / Esc

Printer-friendly Version

Interactive Discussion 
Table A1. Contiued.

\begin{tabular}{|c|c|c|}
\hline $\begin{array}{l}\text { Caviedes hurricanes } \\
\text { series }\end{array}$ & $\begin{array}{l}\text { Chenoweth cyclones } \\
\text { hurricanes }\end{array}$ & $\begin{array}{l}\text { French Antilles } \\
\text { hurricanes series }\end{array}$ \\
\hline & 1816 & \\
\hline & 1817 & 1817 \\
\hline \multirow[t]{8}{*}{1818} & 1818 & \\
\hline & 1819 & 1819 \\
\hline & 1820 & \\
\hline & 1821-1821 & 1821 \\
\hline & 1822-1822 & 1822 \\
\hline & 1824-1824 & 1824 \\
\hline & 1825 & 1825 \\
\hline & 1826 & \\
\hline \multirow{2}{*}{$\begin{array}{l}1827 \\
1828\end{array}$} & 1827 & $1827-1827$ \\
\hline & 1830 & \\
\hline \multirow[t]{4}{*}{1831} & 1831 & 1831-1831 \\
\hline & 1832 & \\
\hline & 1834 & 1834 \\
\hline & 1835 & \\
\hline 1836 & 1836 & \\
\hline 1837 & 1837 & $1837-1837$ \\
\hline 1838 & $\begin{array}{l}1838 \\
1841\end{array}$ & \\
\hline \multirow[t]{5}{*}{1842} & 1842 & \\
\hline & 1843 & \\
\hline & 1844 & \\
\hline & 1845 & \\
\hline & 1846 & \\
\hline 1847 & 1848 & \\
\hline
\end{tabular}

CPD

11, 1519-1550, 2015

The historic reality of the cyclonic

variability in French Antilles

E. Garnier et al.

\section{Title Page}

Abstract

Introduction

Conclusions

References

Tables

Figures

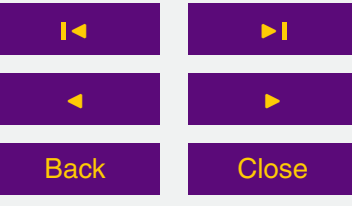

Full Screen / Esc

Printer-friendly Version

Interactive Discussion 
Table A1. Contiued.

\begin{tabular}{|c|c|c|}
\hline $\begin{array}{l}\text { Caviedes hurricanes } \\
\text { series }\end{array}$ & $\begin{array}{l}\text { Chenoweth cyclones } \\
\text { hurricanes }\end{array}$ & $\begin{array}{l}\text { French Antilles } \\
\text { hurricanes series }\end{array}$ \\
\hline & 1849 & \\
\hline \multirow[t]{5}{*}{1850} & 1850 & \\
\hline & 1851 & \\
\hline & 1852 & 1852 \\
\hline & 1854 & \\
\hline & & 1855 \\
\hline \multicolumn{3}{|l|}{1858} \\
\hline \multicolumn{3}{|l|}{$1862-1863$} \\
\hline 1865 & & 1865 \\
\hline \multicolumn{3}{|l|}{1868} \\
\hline 1875 & & 1875 \\
\hline \multicolumn{3}{|l|}{1878} \\
\hline \multicolumn{3}{|l|}{1884} \\
\hline \multicolumn{3}{|l|}{1887} \\
\hline & & 1891 \\
\hline 1893 & & \\
\hline \multicolumn{3}{|l|}{1897} \\
\hline 1898 & & 1898 \\
\hline \multicolumn{3}{|l|}{1901} \\
\hline \multicolumn{3}{|l|}{1906} \\
\hline \multicolumn{3}{|l|}{1911} \\
\hline \multicolumn{3}{|l|}{1913} \\
\hline \multicolumn{3}{|l|}{1914} \\
\hline \multicolumn{3}{|l|}{1916} \\
\hline \multicolumn{3}{|l|}{1917} \\
\hline \multicolumn{3}{|l|}{1922} \\
\hline 1926 & & \\
\hline
\end{tabular}

CPD

11, 1519-1550, 2015

The historic reality of the cyclonic

variability in French Antilles

E. Garnier et al.

\section{Title Page}

Abstract

Introduction

Conclusions

References

Tables

Figures

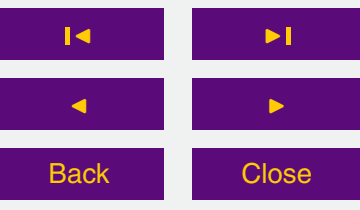

Full Screen / Esc

Printer-friendly Version

Interactive Discussion

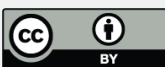


Table A1. Contiued.

\begin{tabular}{|c|c|c|}
\hline $\begin{array}{l}\text { Caviedes hurricanes } \\
\text { series }\end{array}$ & $\begin{array}{l}\text { Chenoweth cyclones } \\
\text { hurricanes }\end{array}$ & $\begin{array}{l}\text { French Antilles } \\
\text { hurricanes series }\end{array}$ \\
\hline & & 1928 \\
\hline \multicolumn{3}{|l|}{1932} \\
\hline \multicolumn{3}{|l|}{1933} \\
\hline \multicolumn{3}{|l|}{1936} \\
\hline \multicolumn{3}{|l|}{1939} \\
\hline \multicolumn{3}{|l|}{1941} \\
\hline \multicolumn{3}{|l|}{1950} \\
\hline & & 1951 \\
\hline \multicolumn{3}{|l|}{1955} \\
\hline & & 1956 \\
\hline \multicolumn{3}{|l|}{1957} \\
\hline \multicolumn{3}{|l|}{1958} \\
\hline \multicolumn{3}{|l|}{1961} \\
\hline & & 1963 \\
\hline & & 1964 \\
\hline \multicolumn{3}{|l|}{1965} \\
\hline & & 1966 \\
\hline \multicolumn{3}{|l|}{1969} \\
\hline \multicolumn{3}{|l|}{1972} \\
\hline \multicolumn{3}{|l|}{1976} \\
\hline \multirow[t]{2}{*}{1979} & & 1979 \\
\hline & & 1980 \\
\hline \multirow{2}{*}{\multicolumn{3}{|c|}{$\begin{array}{l}1983 \\
1988\end{array}$}} \\
\hline & & \\
\hline & & 1989 \\
\hline & & 1995 \\
\hline & & 1997 \\
\hline & & 2007 \\
\hline
\end{tabular}

CPD

11, 1519-1550, 2015

The historic reality of the cyclonic variability in French Antilles

E. Garnier et al.

\section{Title Page}

Abstract

Introduction

Conclusions

References

Tables

Figures

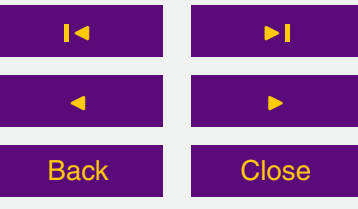

Full Screen / Esc

Printer-friendly Version

Interactive Discussion 


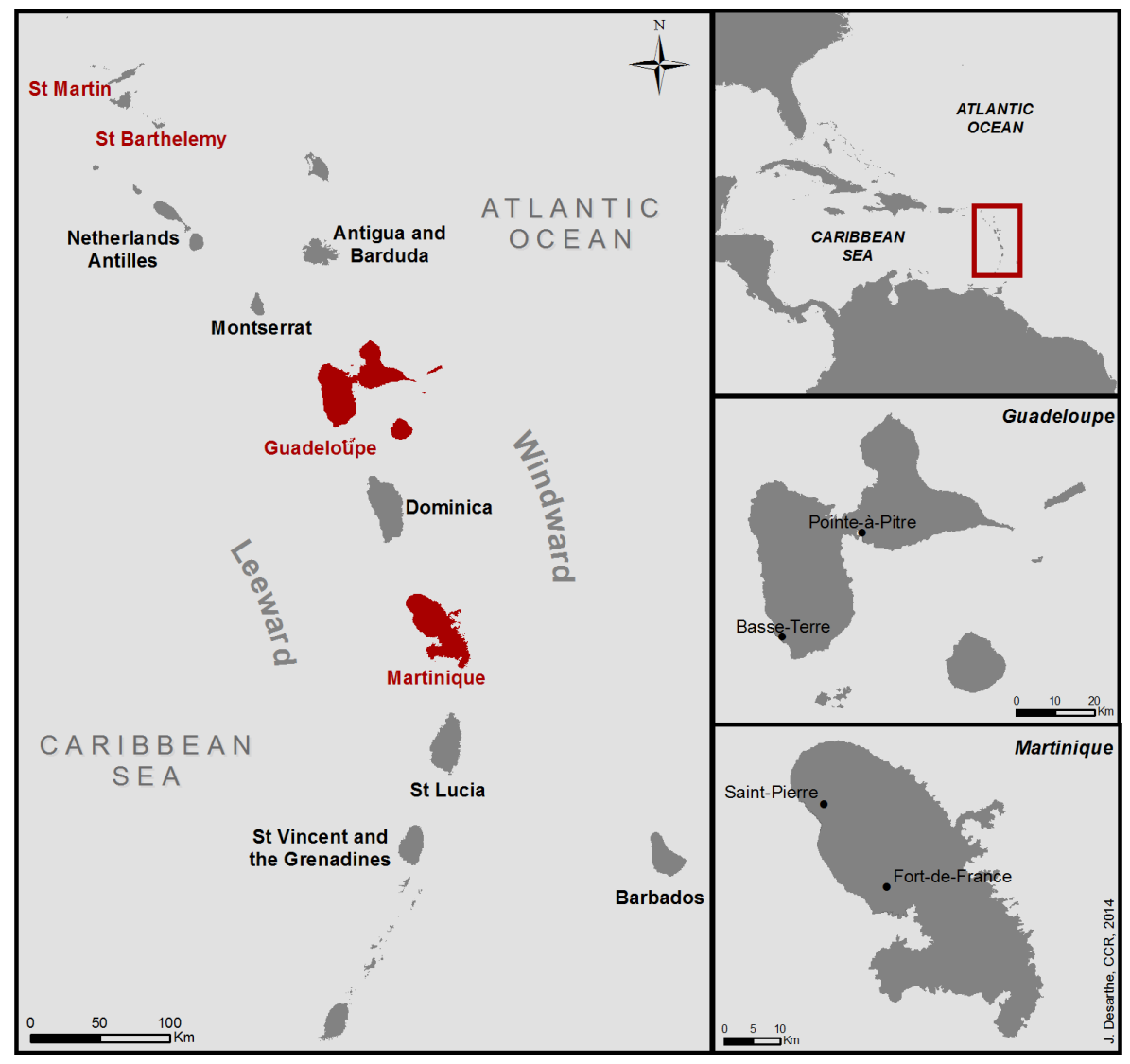

CPD

11, 1519-1550, 2015

The historic reality of the cyclonic variability in French Antilles

E. Garnier et al.

\section{Title Page}
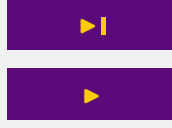

Back

\section{Full Screen / Esc}

Printer-friendly Version

Figure 1. Map of the Antilles. 


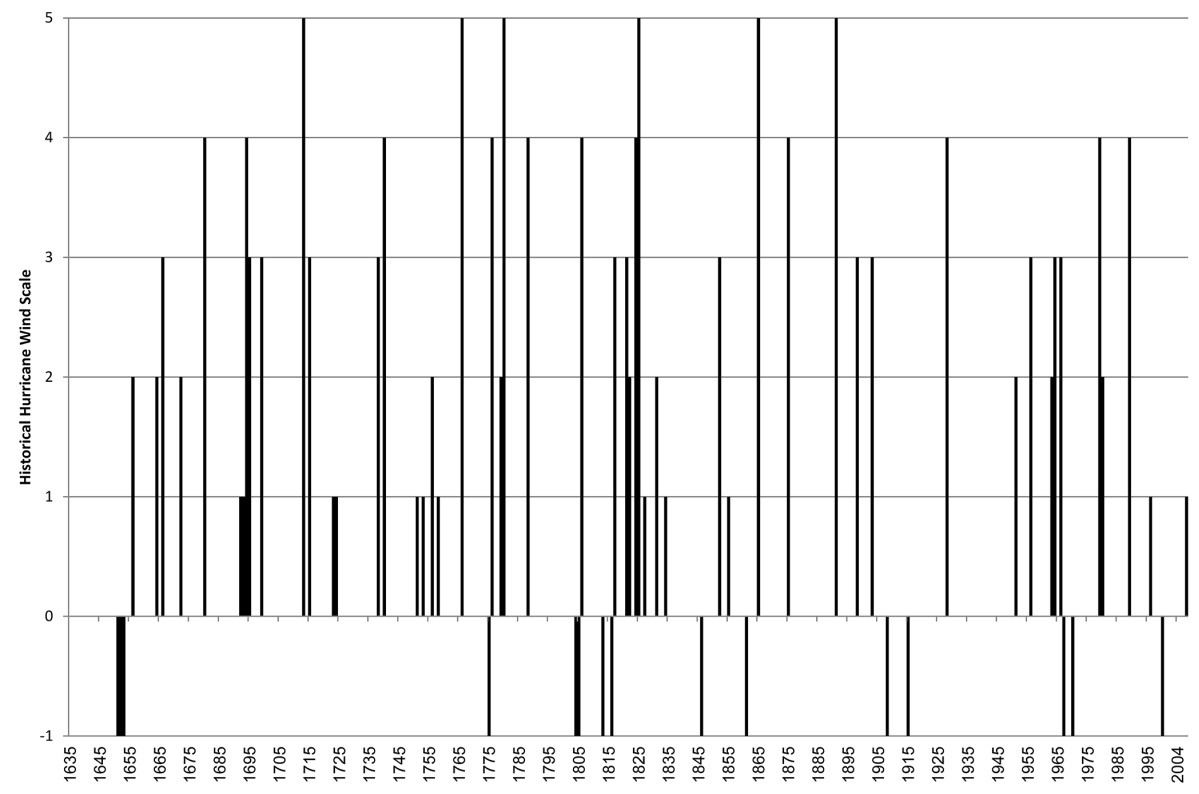

Figure 2. Chronology and severity (according to HHWS) of hurricanes in the French Antilles between 1635 and 2007.
CPD

$11,1519-1550,2015$

The historic reality of the cyclonic variability in French Antilles

E. Garnier et al.

Title Page

Abstract

Introduction

Conclusions

References

Tables

Figures

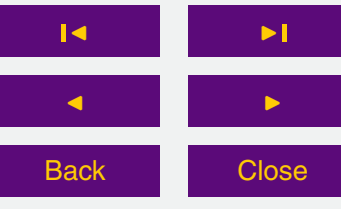

Full Screen / Esc

Printer-friendly Version

Interactive Discussion

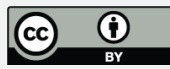




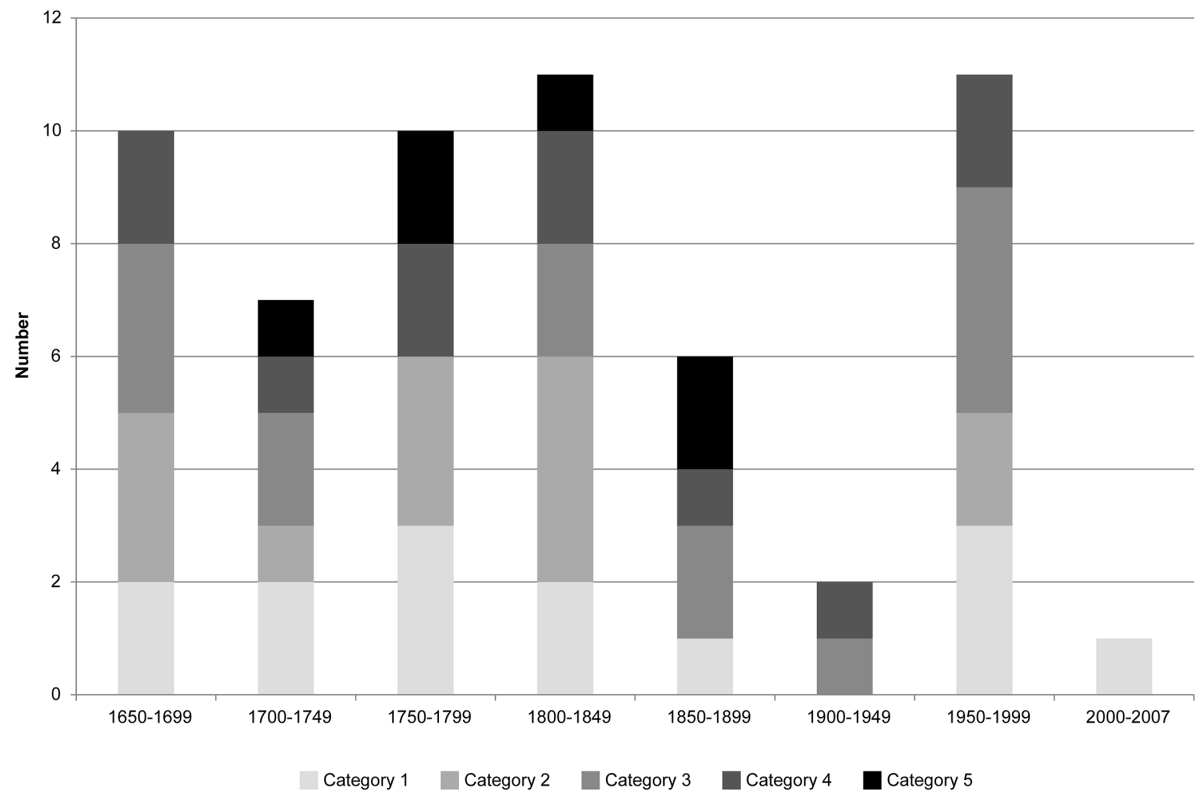

Figure 3. Distribution of hurricanes by periods of 49 years and by category (from 1 to 5 ) of the HHWS in the French Antilles.

\section{CPD}

11, 1519-1550, 2015

The historic reality of the cyclonic variability in French Antilles

E. Garnier et al.

\section{Title Page}
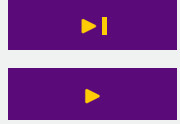

Back

Close

Full Screen / Esc

Printer-friendly Version

Interactive Discussion 


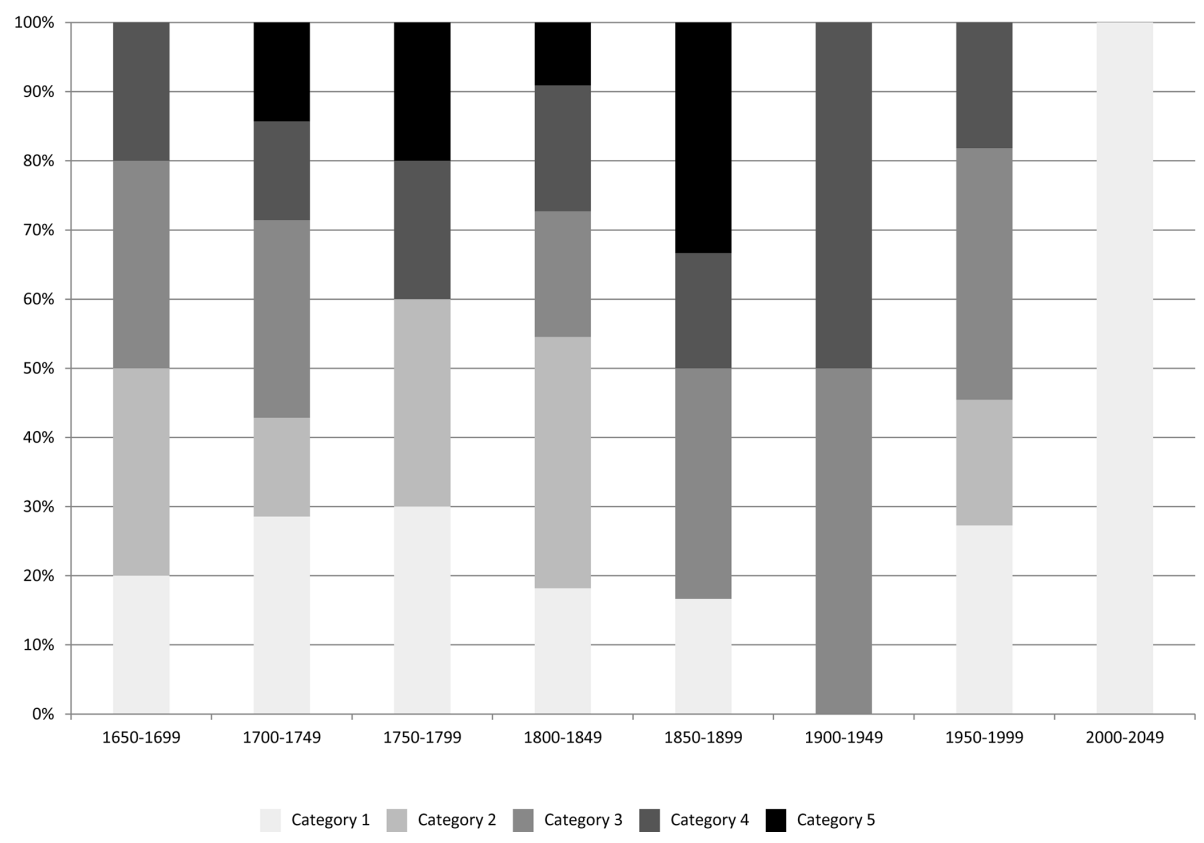

Figure 4. Distribution of cyclones by century and by category (from 1 to 5 ) of the HHWS in the French Antilles (in pourcentage).

\section{CPD}

$11,1519-1550,2015$

The historic reality of the cyclonic variability in French Antilles

E. Garnier et al.

\section{Title Page}
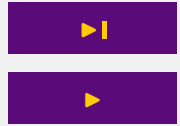

Back

Close

Full Screen / Esc

Printer-friendly Version

Interactive Discussion 


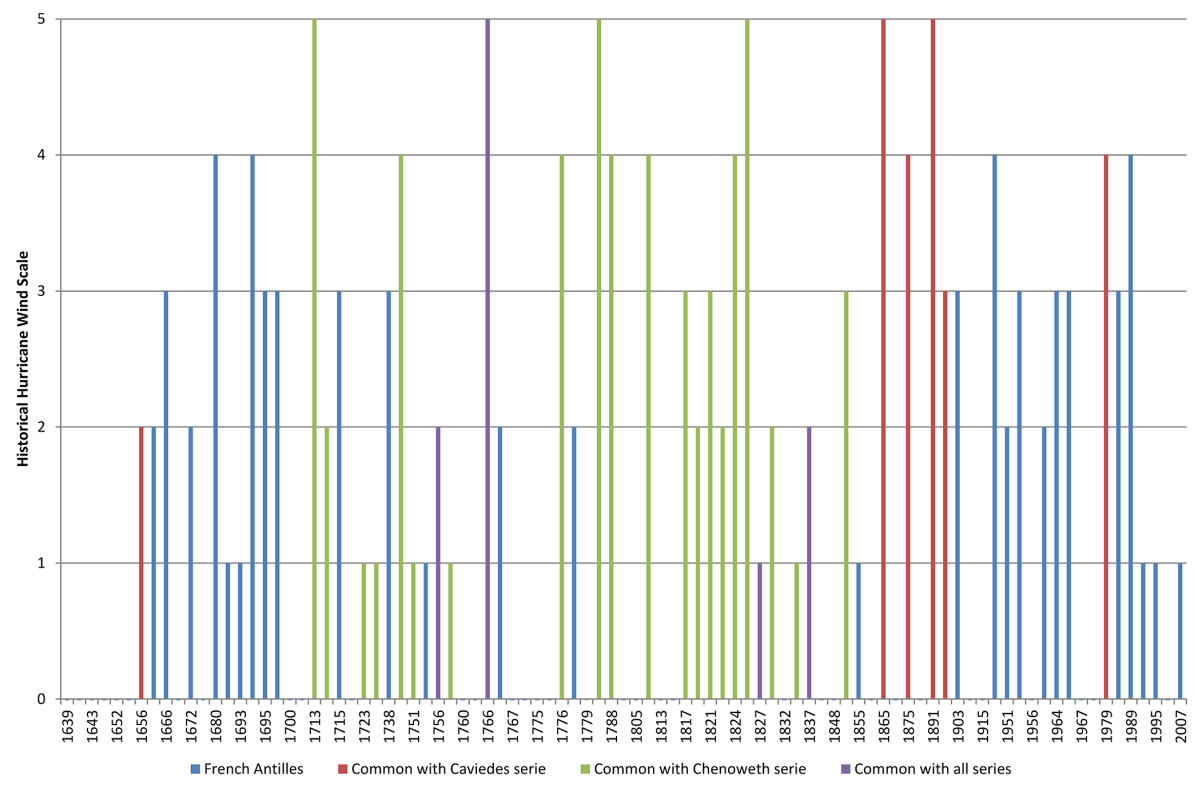

Figure 5. Comparison between cyclones in the French Antilles (Martinique, Guadeloupe, SaintBarthelemy, Saint-Martin) and the series of Caviedes (1991) and Chenoweth (2006). The red dates indicate the common events between Caviedes and the French Antilles series. The green dates indicate the common events between Chenoweth and the French Antilles series. The blue dates indicate a French cyclone quotation by Chenoweth. For more details, see Table A1.

\section{CPD}

$11,1519-1550,2015$

The historic reality of the cyclonic variability in French Antilles

E. Garnier et al.

Title Page

Full Screen / Esc

Printer-friendly Version

Interactive Discussion 